\title{
Relationship Between the Number of Cesarean Deliveries and Maternal-fetal Complications
}

\author{
Sezeryan Sayısının Anne ve Çocuk Komplikasyonları ile iliş̧isi \\ (D) Özgür Deniz Turan, (1) Ezgi Özdemir, (1) Tolga Atakul, (1) Emre Zafer
}

Aydın Adnan Menderes University Faculty of Medicine, Department of Obstetrics and Gynecology, Aydın, Turkey

Keywords

Cesarean, fetal, maternal, complications

Anahtar Kelimeler

Sezeryan, fetal, maternal sonuçlar

Received/Geliş Tarihi : 15.06 .2018

Accepted/Kabul Tarihi : 18.09.2018

doi:10.4274/meandros.galenos.2018.29292

Address for Correspondence/Yazışma Adresi: Özgür Deniz Turan MD,

Aydın Adnan Menderes University Faculty of Medicine, Department of Obstetrics and Gynecology, Aydın, Turkey

Phone : +90 5324481643

E-mail : ozgurdenizturan@gmail.com

ORCID ID: orcid.org/0000-0003-2230-8404

(C) Meandros Medical and Dental Journal, Published by Galenos Publishing House.

This is article distributed under the terms of the Creative Commons Attribution NonCommercial 4.0

International Licence (CC BY-NC 4.0).

\begin{abstract}
Objective: Cesarean operation is very common and it is being performed increasingly all over the world. In this study, the effect of the number of cesarean deliveries on maternal and fetal health was evaluated.

Materials and Methods: We included patients who underwent cesarean section in our clinic between October 2014 and October 2017, who had no additional disease, between 38 and 40 gestational weeks, and ages between 18 and 40 years. Postnatal records were retrospectively reviewed. Patients who had pregnancy complications such as pregnancy hypertension, gestational diabetes, oligohydramnios, polyhydramnios, or who had a dysmorphic appearing baby or with any genetic syndrome were excluded. Patients were divided into three groups according to the number of cesareans they had undergone. Group 1 consisted of patients with history of two cesarean deliveries, group 2 consisted of patients with 3 cesarean deliveries and group three consisted of patients with 4 or more cesarean deliveries. Groups were then compared to each other for their demographic data and maternal - fetal outcomes.

Results: Mean age of the patients studied was 32.4 years [standard deviation (SD): 4.4], mean gestational week was 38 weeks and 2 days (SD: 0.55), and mean hospitalization duration was: 4.4 days (SD: 1.0). There was no significant correlation between the number of cesarean section and the parameters of birth weight, duration of hospital stay, and appearance, pulse, grimace, activity, and respiration scores.

Conclusion: The history for the number of previous cesarean deliveries for a pregnancy may not seem to be correlated with increased maternal or fetal complications up to four previous cesarean deliveries. There is a need for future studies with even larger patients to support our findings.
\end{abstract}

Öz

Amaç: Sezeryan operasyonu tüm dünyada çok yaygın olarak ve giderek artan oranlarda yapılmaktadır. Sunulan bu çalışmada sezeryan sayısının maternal ve fetal sağlığı üzerine etkilerinin incelenmesidir.

Gereç ve Yöntemler: Çalışmaya 1 Ekim 2014 - 1 Ekim 2017 tarihleri arasında kliniğimizde sezeryan operasyonu geçirmiş ve ek hastalığı olmayan, gebelik haftası 38-40 hafta arasında olan, gebeliği 18-40 yaşlarında olan kişiler dahil edilmiştir. $\mathrm{Bu}$ kişilerin doğum sonrası kayıtları retrospektif olarak incelenmiştir. Gebelik 
tansiyonu, gestasyonel diyabet, oligohidramniyoz, polihidroamniyoz gibi gebelik komplikasyonu olan ya da bebeğe ait anomali ya da herhangi bir genetik sendrom tanısı konmuş olan hastalar çalışma dışında bırakıldı. Hastalar sezeryan sayılarına göre üç gruba ayrıldı. Sezeryan sayısı 2 ise grup 1, üç ise grup 2, dört ise grup 3 olarak tanımlandı. Her bir grup demografik veriler, maternal ve fetal sonuçlar açısından karşılaştırıldı.

Bulgular: Çalışmaya alınan hastaların yaş ortalaması 32,4 [standart daviasyon (SD): 4,4], ortalama gebelik haftası: 38 hafta iki gün (SD: 0,55), ortalama hastanede kalma süreleri: 4,4 (SD: 1,0). gündü Sezeryan sayısı ile doğum ağırlığı, hastanede kalış süresi, 1 . ve 5. dakika görünüm, nabız, yüz buruşturma, etkinlik ve solunum skorları arasında anlamlı korelasyon gözlenmedi.

Sonuç: Dördüncü sezeryan sayısına kadar geçirilmiş sezeryan öyküsü; gebelikte maternal ve fetal komplikasyonlarla korelasyon göstermeyebilir. Bulgularımızı desteklemek için gelecekte daha büyük hastalarla yapılacak olan çalışmalara ihtiyaç vardır.

\section{Introduction}

The cesarean section is the most commonly performed obstetric operation in the world. The rates of cesarean operation in recent years have increased in many countries as well as in Turkey. It has been reported that cesarean rates have increased by $10-$ $15 \%$ over the last 30 years throughout the world (1). In Turkey, while 8\% cesarean rate was reported in 1993, it has risen to $37 \%$ in 2008 . Despite the increased cesarean rates, the rate of tubal sterilization incidence among married women in our country has been reported to be only $2.7 \%$ (2).

It is well known that cesarean section operation has a significantly increased maternal mortality and morbidity risk compared to normal vaginal birth $(3,4)$. Postpartum maternal complications of cesarean sections may include wound infection, endometritis, bladder injury complications related to blood transfusions, hemorrhage, disseminated intravascular coagulation and urinary tract infections. Important possible fetal-neonatal complications are neonatal asphyxia, respiratory distress syndrome, transient tachypnea neonatal sepsis and neonatal morbidity (5).

Increased number of cesarean rates has been shown to be correlated with decreased fertility, increased early pregnancy loss, higher ectopic pregnancy rates, and low birth weight $(6,7)$.

Therefore, we aimed to investigate the relationship between the history of previous number of cesarean deliveries and maternal-fetal outcomes.

\section{Materials and Methods}

The study was approved by the Ethics Committee for Research of the Adnan Menderes University (19/02/2018-E.10086), and informed written consent was obtained from all subjects.
Ninety-two pregnant women between the ages of 18-40, who had a cesarean section in our clinic between October 2014 and October 2017 with no additional disease, between the ages of 38-40 weeks of gestation were retrospectively screened and included in the study. All cesarean operations had been performed by low segment transverse incision under regional spinal anesthesia. Patients who had had pregnancy complications such as gestational hypertension, gestational diabetes mellitus, oligohydramnios, polyhydroamnios, intrauterine growth retardation, multiple pregnancy, or who had a dismorphic baby or baby with genetic syndrome were excluded from the study. Cases were divided into three groups according to the personal history for previous cesarean numbers. Group 1: those who had two cesarean operations, group 2: those who had three cesarean operations, and group 3: women who had four cesarean delivery histories. Demographic data, maternal and fetal outcomes of each group were then compared to each other.

\section{Statistical Analysis}

The program SPSS 12 was used for statistical analyses (SPSS Inc., Chicago, IL, USA). The t-test was used to compare normal distribution of variables, ANOVA test was used to compare more than two groups with one dependent variable. A value of $p<0.05$ was considered as statistically significant.

\section{Results}

In our study we retrospectively screened 220 patients records who delivered with caesarean section. Pregnants with complication were excluded and a total of 92 patients were included in the study The study design is shown in the Figure 1 . The mean age for the studied population was 32.4 years [standard deviation (SD): 4.4], mean gestational week was 38 weeks and 2 days, mean hospitalization time: 
4.4 days (SD: 1.0). Demographic data was given in Table 1.

There was no significant difference with respect to maternal age among groups $(p=0.806)$. Smoking rates

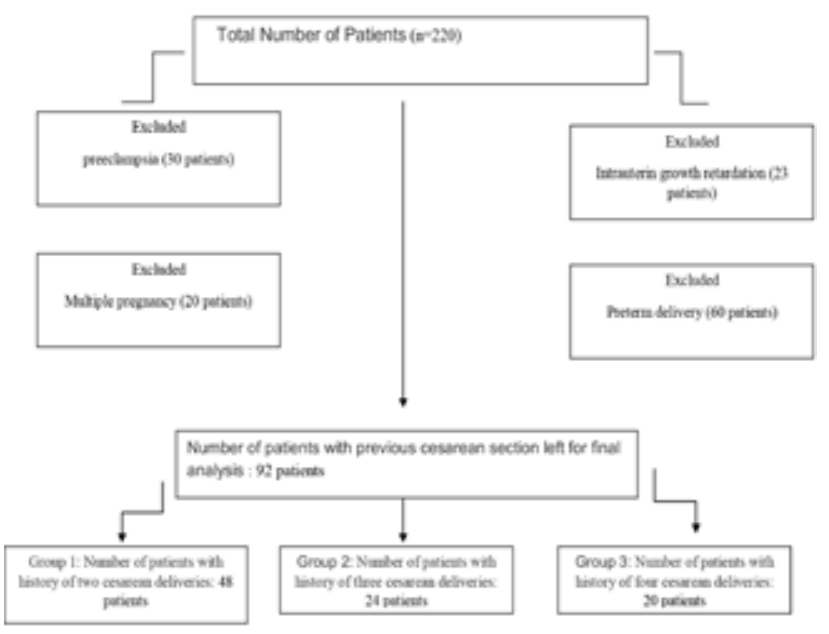

Figure 1. Study Design were not significantly different either $(p=0.958)$. The rate of higher education was $78.3 \%$ in the first group, $21.7 \%$ in the second group and $0 \%$ in the third group $(p=0.09)$. When the fetal status was evaluated, no significant differences were found among the groups in terms of gestational age, birth weight, first and fifth minute appearance, pulse, grimace, activity, and respiration (APGAR) scores ( $p>0.05)$.

There was no significant correlation between birth weight and number of cesarean section, duration of hospital stay, and $1^{\text {st }}$ and $5^{\text {th }}$ minute APGAR scores (Table 2 and 3 ).

\section{Discussion}

Cesarian rates are increasing in Turkey as well as in the majority of other countries. In this study, there was no significant difference between the groups in terms of demographic data.

As the number of previous cesarean deliveries increases, the duration of operation prolongs due

\begin{tabular}{|c|c|c|c|c|}
\hline & $\begin{array}{l}\text { Group } 1 \\
(n=48)\end{array}$ & $\begin{array}{l}\text { Group } 2 \\
(n=24)\end{array}$ & $\begin{array}{l}\text { Group } 3 \\
(n=20)\end{array}$ & $\mathbf{p}$ \\
\hline $\begin{array}{l}\text { Maternal age } \\
\text { [year, mean (SD)] }\end{array}$ & $32.1(4.76)$ & $32.7(3.28)$ & $32.0(4.31)$ & 0.797 \\
\hline Gestational week at birth [mean (SD)] & $38.2(0.43)$ & $38.2(0.55)$ & $38.0(0.44)$ & 0.195 \\
\hline Body mass index $\left[\mathrm{kg} / \mathrm{m}^{2}\right.$, mean $\left.(\mathrm{SD})\right]$ & $28.2(3.61)$ & $28.39(5.64)$ & $28.0(5.04)$ & 0.972 \\
\hline Post-operative hemoglobin level [g/dL, mean (SD)] & $10.6(1.15)$ & $10.0(1.24)$ & $10.3(1.46)$ & 0.187 \\
\hline Hospitalization time [day, mean (SD)] & $4.3(0.93)$ & $4.5(1.28)$ & $4.5(1.19)$ & 0.765 \\
\hline APGAR 1. minute [mean (SD)] & $7.8(0.80)$ & $7.9(0.85)$ & $8.1(0.71)$ & 0.634 \\
\hline APGAR 5. minute [mean (SD)] & $9.1(0.55)$ & $9.1(0.53)$ & $9.1(0.58)$ & 0.987 \\
\hline
\end{tabular}

Table 2. Correlation between the history of previous cesarean delivery number and fetal outcomes

\begin{tabular}{|l|l|l|l|l|l|l|}
\hline & $\begin{array}{l}\text { Fetal Weight } \\
\text { [gr, mean (SD)] }\end{array}$ & $\mathbf{p}$ & $\begin{array}{l}\text { APGAR at first minute } \\
\text { [mean (SD)] }\end{array}$ & $\begin{array}{l}\text { APGAR at fifth } \\
\text { minute [mean (SD)] }\end{array}$ & $\mathbf{p}$ \\
\hline Number of cesarean delivery & $3260.5(459.57)$ & 0.220 & $7.9(0.79)$ & 0.270 & $9.1(0.57)$ \\
\hline
\end{tabular}

Table 3. Correlation between the history of previous cesarean delivery number and maternal outcomes

\begin{tabular}{|l|l|l|}
\hline & Number of cesarean delivery & $\mathbf{p}$ \\
\hline Post-operative hemoglobin level [g/dL, mean (SD)] & $10.4(1.27)$ & 0.454 \\
\hline Hospitalization time [day, mean (SD)] & $4.4(1.06)$ & 0.501 \\
\hline
\end{tabular}


to increased intra-abdominal adhesions, and postoperative hemoglobin levels may decrease as reported in some studies (8). In this study, the history for previous cesarean delivery number was not found to be significantly correlated with hemoglobin levels ( $p>0.005)$. The reason for his may be related to our relatively shorter than expected operation time even in the 4th cesarean procedures. The other reason may be our relatively lower complication rates.

In our study, we studied the possible correlation between the number of previous cesarean deliveries and maternal-fetal complications in cases with two or more cesarean section histories. In this study, increased cesarean rates and risk of maternal morbidity were not found to be related. Similar to our study, Rashid and Rashid (9) reported that increasing the number of previous caesarean sections in terms of maternal morbidity was not a risk. However, contrary to our results, increased maternal mortality and morbidity rates with increasing cesarean ratios have also been reported (10-13). In addition, it has been shown that the number of previous cesarean deliveries is directly proportional to the risk of morbidly adhesive diseases of placenta. The incidence of accreta continued to rise with increasing previous cesarean deliveries, up to $6.74 \%$ for women with previous cesarean deliveries compared with no previous $C D$, with an odds ratio of 29.8 (11). Compared with previous normal spontaneous vaginal delivery, previous cesarian delivery was a significant risk factor for placenta previa in many studies (14-21). The highest number of previous cesarean delivery in our study was four. It was reported in a study from Turkey that was conducted on 2460 patients, critical complications developed when there were 4 or more previous cesarean delivery histories (10). The reason for low rate of maternal complications in our study may be due to the lack of cases with more than 4 previous cesarean deliveries.

In this study, there was no difference between the neonatal APGAR scores with respect to the number of previous cesarean sections. Similarly to our findings, in the study of Rashid and Rashid. (9) there was no difference in the APGAR scores whom had 5 to 9 previous cesarean operations when compared to 3 or 4 previous cesarean operations (9). Contrary to these results, it was observed that the APGAR scores were significantly deteriorated in the group of cesarean section in Yaman Tunc et al. (22) study.

Retrospective design, the small number of patients can be regarded as the limitation of our study. A prospective study design that would compare the maternal - fetal outcomes for the number of previous cesarean deliveries and also of patients with previous vaginal deliveries would be interesting. the small number of patients

\section{Conclusion}

In conclusion, the history of previous cesarean delivery number until four previous cesarean may not increase baseline maternal or fetal complication risk. However, there is a need for prospective controlled studies involving more patients to support our finding.

\section{Ethics}

Ethics Committee Approval: The study was approved by the Ethics Committee for Research of the Adnan Menderes University (19/02/2018-E.10086).

Informed Consent: Informed written consent was obtained from all subjects.

Peer-review: Internally peer-reviewed.

\section{Authorship Contributions}

Surgical and Medical Practices: Ö.D.T., Concept: Ö.D.T., Design: E.Ö., T.A., Data Collection or Processing: E.Ö., E.Z., Analysis or Interpretation: Ö.D.T., T.A., Literature Search: E.Z., Writing: Ö.D.T.

Conflict of Interest: No conflict of interest was declared by the authors.

Financial Disclosure: The authors declared that this study received no financial support.

\section{References}

1. Saleh AM, Dudenhausen JW, Ahmed B. Increased rates of cesarean sections and large families: a potentially dangerous combination. J Perinat Med 26;45: 517-21.

2. Ministry of Health General Directorate of Mother and Child Health/Family Planning (Turkey), Hacettepe University Institute of Population Studies, Macro International Inc., Turkey Demographic and Health Survey 1998, Ankara.

3. Gregory KD, Jackson S, Korst L, Korst L, Fridman M. Cesarean versus vaginal delivery: whose risks? Whose benefits? Am J Perinatol 2012; 29: 7-18.

4. Huang $X$, Lei J, Tan H, Walker M, Zhou J, Wen SW. Cesarean delivery for first pregnancy and neonatal morbidity and mortality in second pregnancy. Eur J Obstet Gynecol Reprod Biol 2011; 158: 204-8. 
5. Yang XJ, Sun SS. Comparison of maternal and fetal complications in elective and emergency cesarean section: a systematic review and meta-analysis. Arch Gynecol Obstet 2017; 296: 503-12.

6. Hall MH, Campbell DM, Fraser C, Lemon J. Mode of delivery and future fertility. British J Obstet Gynaecol, 1989; 96: 1297- 303.

7. Hemminki E. Impact of caesarean section on future pregnancy a reviewof cohort studies. Paediatr Perinat Epidemiol 1996; 10: 366-79.

8. Çintesun E, Al RA. The effect of increased number of cesarean on maternal and fetal outcomes. Ginekol Pol 2017; 88: 613-19.

9. Rashid M, Rashid RS. Higher order repeat caesarean sections: how safe are five or more? BJOG 2004; 111: 1090-4.

10. Kaplanoglu M, Bulbul M, Kaplanoglu D, Bakacak SM3. Effect of multiple repeat cesarean sections on maternal morbidity: data from southeast Turkey. Med Sci Monit 2015; 21: 1447-3.

11. Marshall NE, Fu R, Guise JM. Impact of multiple cesarean deliveries on maternal morbidity: a systematic review. Am J Obstet Gyneco. 2011; 205: 262.e1-8.

12. Uygur D, Gun O, Kelekci S, Ozturk A, Ugur M, Mungan T. Multiple repeat caesarean section: is it safe? Eur J Obstet Gynecol Reprod Biol 2005; 119: 171-5.

13. Uyanikoglu H, Karahan MA, Turp AB, Agar M, Tasduzen ME, Sak $\mathrm{S}$, et al. Are multiple repeated cesarean sections really as safe? J Matern Fetal Neonatal Med 2017; 30: 482-5.

14. Rouse DJ, MacPherson C, Landon M, Varner MW, Leveno KJ, Moawad $\mathrm{AH}$, et al. Blood transfusion and cesarean delivery. Obstet Gynecol 2006; 108: 891-7.
15. Hershkowitz R, Fraser D, Mazor M, Leiberman JR. One or multiple previous cesarean sections are associated with similar increased frequency of placenta previa. Eur J Obstet Gynecol Reprod Biol 1995; 62: 185-8.

16. Odibo AO, Cahill AG, Stamilio DM, Stevens EJ, Peipert JF, Macones GA. Predicting placental abruption and previa in women with a previous cesarean delivery. Am J Perinatol 2007; 24: 299-305.

17. Gilliam M, Rosenberg D, Davis F. The likelihood of placenta previa with greater number of cesarean deliveries and higher parity. Obstet Gynecol 2002; 99: 976-80.

18. Laughon SK, Wolfe HM, Visco AG. Prior cesarean and the risk for placenta previa on second-trimester ultrasonography. Obstet Gynecol 2005;105:962-5.

19. lacovelli $A$, Liberati $M$, Khalil A, Timor-Trisch I, Leombroni $M$, Buca $D$, et al. Risk factors for abnormally invasive placenta: a systematic review and meta-analysis. J Matern Fetal Neonatal Med 2018; 22: 1-11.

20. Taylor VM, Kramer MD, Vaughan TL, Peacock S. Placenta previa and prior cesarean delivery: how strong is the association? Obstet Gynecol 1994; 84: 55-7.

21. Olive EC, Roberts CL, Algert CS, Morris JM. Placenta praevia: maternal morbidity and place of birth. Aust N Z J Obstet Gynaecol 2005; 45: 499-504.

22. Yaman Tunc S, Agacayak E, Sak S, Basaranoglu S, Goruk NY, Turgut $A$, et al. Multiple repeat caesarean deliveries: do they increase maternal and neonatal morbidity? J Matern Fetal Neonatal Med. 2017; 30: 739-44. 